\title{
The marine arthropods from the Solnhofen Lithographic Limestones (Late Jurassic, Germany) in the collections of the Muséum national d'Histoire naturelle, Paris
}

\author{
Sylvain CHARBONNIER \\ Muséum national d'Histoire naturelle, Département Histoire de la Terre, \\ UMR 7207 CNRS, Centre de Recherche sur la Paléobiodiversité \\ et les Paléoenvironnements, \\ case postale 38, 57 rue Cuvier, F-75231 Paris cedex 05 (France) \\ scharbonnier@mnhn.fr \\ Alessandro GARASSINO \\ Museo di Storia Naturale di Milano, \\ Sezione di Paleontologia, \\ Corso Venezia 55, I-20121 Milano (Italia) \\ alegarassino@gmail.com
}

KEY WORDS

Crustacea,

Decapoda,

Jurassic,

Tithonian,

Kimmeridgian,

Solnhofen,

Eichstätt,

Franconia,

Germany,

paleontological collections.

MOTS CLÉS

Crustacea,

Decapoda,

Jurassique,

Tithonien,

Kimméridgien,

Solnhofen,

Eichstätt,

Franconie,

Allemagne,

collections

paléontologiques.
Charbonnier S. \& Garassino A. 2012. - The marine arthropods from the Solnhofen Lithographic Limestones (Late Jurassic, Germany) in the collections of the Muséum national d'Histoire naturelle, Paris. Geodiversitas 34 (4): 857-871. http://dx.doi.org/10.5252/g2012n4a8

\section{ABSTRACT}

The palaeontological collections of the Muséum national d'Histoire naturelle, Paris, France, house a broad range of marine arthropods from the Solnhofen Lithographic Limestones (Late Jurassic, Germany). These arthropods include decapod crustaceans, stomatopods, supposed mysidaceans, and limulids. A commented systematic list is proposed in order to give to the specialists an instrument of comparison and reference.

\section{RÉSUMÉ}

Les arthropodes marins des Calcaires lithographiques de Solnhofen (Jurassique supérieur, Allemagne) dans les collections du Muséum national d'Histoire naturelle, Paris. Les collections paléontologiques du Muséum national d'Histoire naturelle, Paris, France, renferment un ensemble d'arthropodes marins provenant des Calcaires lithographiques de Solnhofen (Jurassique supérieur, Allemagne). Ces arthropodes incluent des crustacés décapodes, des stomatopodes, des mysidacés présumés et des limules. Une liste systématique commentée est proposée dans le but de fournir aux spécialistes un outil de comparaison et de référence. 


\section{INTRODUCTION}

The palaeontological collections of the Muséum national d'Histoire naturelle, Paris, house a number of specimens of marine arthropods from the Solnhofen Lithographic Limestones (Bavaria, Germany) including decapod crustaceans, stomatopods, mysidaceans, and limulids. The Solnhofen collection is composed of several generations of material added over the last 250 years. This collection was mainly derived from specimens accumulated by scientific changes between the Paris Muséum and different German museums and institutions. Other material was also collected by the French Revolutionary armies and during the Napoleonic wars. Moreover, a group of specimens was traded in the late 19th century to different fossil sellers. The scientific changes were supported by some very important French professors such as Barthélemy Faujas de Saint-Fond (17411819), Anselme-Gaétan Desmarest (1781-1838), Alexandre Brongniart (1770-1847) and above all Alphonse Milne Edwards (1835-1900). Other specimens came from changes with other museums (e.g., Manchester Museum) and donations by fortunate collectors (e.g., Boué, de Roissy, de Drée, du Mouy, Stuer) that sometimes collaborated with the Paris Muséum professors. Sometimes, fossil specimens were traded to some famous sellers such as Émile Deyrolle (Paris, 46 rue du Bac, since 1831), Louis Saemann (Paris, between 1850 and 1866), Meyrat (Basel, Comptoir Géologique à Birsfelden), Grebel, Wendler \& Company (Geneva, Comptoir Minéralogique et Géologique Suisse, between 1905 and $c$. 1917), Jean Danhauser (Paris, Comptoir Minéralogique et Géologique, 51 rue de Seine, between 1832 and 1836) and Dr. F. Krantz (Bonn, Rheinisches Mineralien-Kontor GmbH \& Co. KG, since 1833).

The "Konservat-Lagerstätte of Solnhofen" is well known since the beginning of the $18^{\text {th }}$ century and it is still subject of interest by the specialists of the world. Therefore, the aim of the present study is to propose a commented list of the marine arthropods from the Solnhofen Lithographic Limestones housed in the Paris Muséum. Indeed, several specimens housed in old collections in the Paris Muséum, are rather well preserved and totally unknown to date. After their taxonomic identification, we have decided to illustrate some of these specimens in order to give to the specialists an instrument of comparison and reference.

\section{MATERIAL AND METHODS}

\section{COLLECTION ARRANGEMENT}

The history of the palaeontological collections housed in the Paris Museum is complicated because these collections are the heritage of different arrangements from the Royal Cabinet of Natural History to the public collections of the new Muséum of Natural History in 1793. In this time, the department of palaeontology did not exist at the Paris Muséum and fossils were distributed into different collections: geology, botany, mineralogy. In 1853, when the chair of palaeontology was especially created for Alcide d'Orbigny, numerous professors of the Museum refused to give him their fossils to constitute a new palaeontological collection (Brygoo 2002; Vénec-Peyré 2002). This conflicting situation explains the dispersion of the fossils into the Paris Museum. For instance, the type specimens of Eryon cuvieri Desmarest, 1817, were forgotten in a drawer of the geological collection during almost two centuries and recently rediscovered by one of the authors (S. Charbonnier). Today, this situation is quite solved but there are always numerous fossils housed in the geological collection. Consequently, this study includes specimens housed into different buildings having at the same time different catalogue numbers.

\section{FOSSIL LOCALITIES}

As reported by Garassino \& Schweigert (2006), the lithographic limestones of the Late Jurassic in southern Germany (Bavaria) comprise a large set of localities usually summarized under the name "Solnhofen". The study of the Paris collections has allowed identifying mainly three localities: Solnhofen, Eichstätt and Pappenheim. However, the specimens reported as discovered in Pappenheim are probably from other locality. Indeed, the town of Pappenheim is located in the valley of the 
Altmühl River, $5 \mathrm{~km}$ north of the outcrop area of the Solnhofen Lithographic Limestones, and probably these specimens were purchased there from some local persons (Günter Schweigert pers. comm. 2011). Following the last geological setting by Schweigert (2007), the Solnhofen Lithographic Limestones range from the late Kimmeridgian to the early Tithonian (Late Jurassic). The "classical" lithographic limestones of Solnhofen have an early Tithonian age clearly younger than those of the nearby Eichstätt district.

\section{ABBREVIATIONS}

MNHN.F

MNHN.GG

Muséum national d'Histoire naturelle, Paris (France), Collection de Paléontologie.

Muséum national d'Histoire naturelle, Paris (France), Collection de Géologie.

\section{SYSTEMATICS}

The following listing of crustaceans (including Decapoda, Stomatopoda, Mysidacea) and limulids (Xiphosurida) housed in the Paris Museum is arranged taxonomically. This commented systematic list includes 106 specimens identified as follows:

\section{AEGERIDAE}

Aeger spinipes (Desmarest, 1817) (1 specimen); Aeger tipularius (von Schlotheim, 1822) (7 specimen); Acanthochira longipes (Oppel, 1862) (1 specimen).

\section{Penaeidae}

Antrimpos speciosus Münster, 1839 (6 specimens); Rauna angusta Münster, 1839 (1 specimen); Bylgia hexadon Münster, 1839 (1 specimen); Albertoppelia kuempeli Schweigert \& Garassino, 2004 (1 specimen);

Drobna deformis Münster, 1839 (1 specimen).

\section{CARIDEA}

Hefriga serrata Münster, 1839 (2 specimens).

\section{ERYMIDAE}

Eryma modestiforme (von Schlotheim, 1822) (8 specimens);

Palaeastacus fuciformis (von Schlotheim, 1822) (3 specimens).

GLYPHEIDAE

Glyphea pseudoscyllarus (von Schlotheim, 1822) (4 specimens).

\section{MECOCHIRIDAE}

Mecochirus longimanatus (von Schlotheim, 1820) (27 specimens).

PaLinURIDAE

Palinurina longipes Münster, 1839 (8 specimens).

ERYONIDAE

Cycleryon propinquus (von Schlotheim, 1822) (5 specimens);

Cycleryon orbiculatus (Münster, 1839) (1 specimen); Eryon cuvieri Desmarest, 1817 (16 specimens).

\section{SCULDIDAE}

Sculda pennata Münster, 1840 (1 specimen).

\section{MYSIDACEA}

Elder ungulatus Münster, 1839 (3 specimens).

\section{LIMULIDAE}

Mesolimulus walchii (Desmarest, 1817) (4 specimens).

\section{REMARKS}

Some specimens belonging to the penaeids (10 specimens), erymids (1 specimen), mecochirids (1 specimen) and eryonids (2 specimens) do not show the main diagnostic characters to identify them at specific level. Most of them correspond to fragmentary and/or incomplete remains. Therefore, we do not consider them in the commented list. Moreover, three specimens corresponding to larval stage of decapod crustaceans are tentatively attributed to Phalangites Münster, 1836. Their poorly preservation does not allow supplementary dissertation (see Polz 1970-1973).

In conclusion, each identified species is listed, as follows: the specimen number, collecting locality, collector (when known), and comment. The type species is given also for each taxon. The systematic arrangement follows De Grave et al. (2009). 


\section{COMMENTED SYSTEMATIC LIST}

Class MALACOSTRACA Latreille, 1802

Superorder EUCARIDA Calman, 1904

Order DECAPODA Latreille, 1802

Suborder DENDROBRANCHIATA Bate, 1888

Superfamily PENAEOIDEA Rafinesque, 1815

Family AEGERIDAE Burkenroad, 1963

Genus Aeger Münster, 1839

TYPE SPECIES. - Macrourites tipularius von Schlotheim, 1822, by subsequent designation of Woods (1925).

\section{Aeger spinipes (Desmarest, 1817)}

(Fig. 1A)

STUdied MATERIAL. - 1 specimen from Eichstätt (MNHN.F.B13441).

\section{COMMENTS}

This specimen exhibits a long, narrow rostrum which is typical of $A$. spinipes, whereas Aeger tipularius (von Schlotheim, 1822) exhibits only a very short, hook-like rostrum. See Schweigert (2001a) for more detailed discussion.

\section{Aeger tipularius (von Schlotheim, 1822)}

(Fig. 1B)

STUdied MATERial. - 4 specimens from Solnhofen (MNHN.F.A33509, B13442, R03389; MNHN. GG.2004/57291), 2 specimens from Eichstätt (MNHN.F.B13440, B13443), 1 specimen from unknown locality (MNHN.GG.2004/8072). Collections A. Milne Edwards, Schwarzchild, Hoffstetter.

\section{COMMENTS}

The figured specimen is relatively poorly preserved and is assigned to $A$. tipularius with doubt because several diagnostic characters have probably remained on the counter plate which is not in the collection. Note that one other species of this genus $-A$. elegans Münster, 1839 - is known from the Solnhofen Lithographic Limestones but is not present in the Paris collection.

\section{Genus Acanthochirana Strand, 1928}

TYPE SPECIES. - Udora cordata Münster, 1839 (partim), by subsequent designation of Glaessner (1929).

\section{Acanthochira longipes (Oppel, 1862)}

(Fig. 1C)

STUdied MATERIAL. - 1 specimen from Eichstätt (MNHN.F.A42003).

\section{COMMENTS}

The examined specimen is assigned to $A$. longipes because the third maxillipeds are longer than those of the type species $A$. cordata (Münster, 1839), also from the Solnhofen Lithographic Limestones.

\section{Family Penaeidae Rafinesque, 1815}

$$
\text { Genus Antrimpos Münster, } 1839
$$

TYPE SPECIES. - Antrimpos speciosus Münster, 1839, by subsequent designation of Glaessner (1929).

\section{Antrimpos speciosus Münster, 1839}

(Fig. 2A)

STUDIED MATERIAL. -4 specimens from Solnhofen (MNHN.F.A33519, A33548, R03502, A33504); 1 specimen from Eichstätt (MNHN.F.B13465); 1 specimen from unknown locality (MNHN.GG.2004/8086). Collections Boué, de Roissy, Hoffstetter, Manchester Museum.

\section{COMMENTS}

The figured specimen (MNHN.F.R03502) is remarkably long (total length: $26 \mathrm{~cm}$ ) and corresponds probably to an exuvia because its cephalothorax is dislocated. The same disarticulation is observed on the specimen MNHN.F.A42004 (Fig. 2B).

\section{Genus Rauna Münster, 1839}

TYPE SPECIES. — Rauna angusta Münster, 1839, by monotypy. 

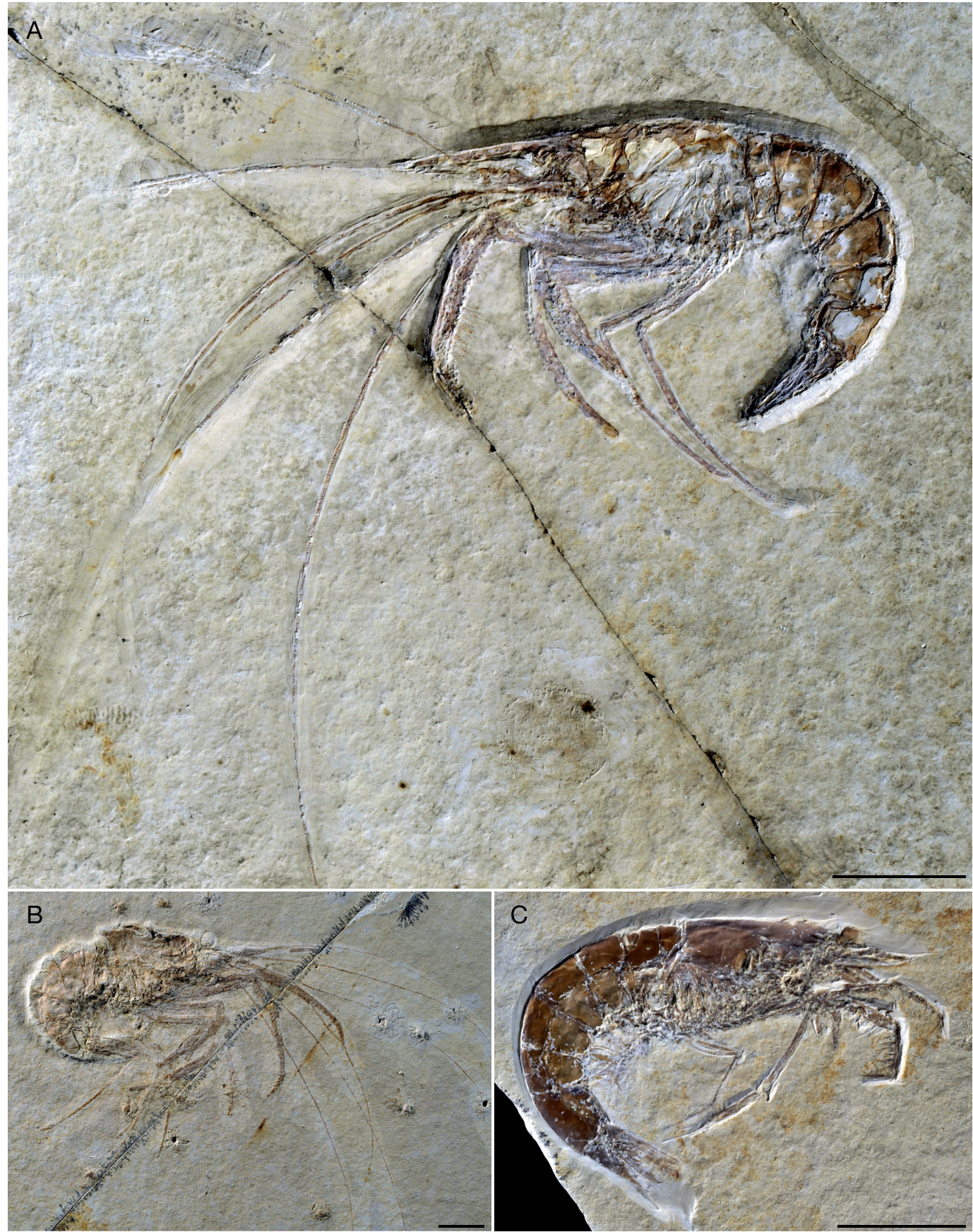

FIG. 1. - Aegeridae from the Late Jurassic Solnhofen Lithographic Limestones (Bavaria, Germany): A, Aeger spinipes (Desmarest, 1817), right lateral view (MNHN.F.B13441, Eichstätt); B, A. tipularius (von Schlotheim, 1822), left lateral view (MNHN.F.B13440, Eichstätt); C, Acanthochira longipes (Oppel, 1862), left lateral view, (MNHN.F.A42003, Eichstätt). Scale bars: 2 cm. Photographs by C. Lemzaouda (MNHN). 
Rauna angusta Münster, 1839

(Fig. 2B)

STUdied Material. -1 specimen from Solnhofen (MNHN.F.A42004). Collection Boué.

\section{COMMENTS}

The figured specimen is very probably an exuvia. The preservation is typical for some limestones from Solnhofen and especially for this species, which is Rauna angusta Münster, 1839, because of the carapace with a longitudinal crest near the dorsal line.

Genus Bylgia Münster, 1839

TYPE SPECIES. - Bylgia spinosa Münster, 1839, by subsequent designation of Oppel (1862).

\section{Bylgia hexadon Münster, 1839}

STUDied MATERIAL. - 1 specimen from Solnhofen (MNHN.F.A33503).

\section{COMMENTS}

The specimen is assigned to $B$. hexadon because the rostrum is short and straight while it is directed upward in B. spinosa Münster, 1839.

Genus Albertoppelia Schweigert \& Garassino, 2004

TyPE SPECIES. - Albertoppelia kuempeli Schweigert \& Garassino, 2004, by monotypy.

\section{Albertoppelia kuempeli \\ Schweigert \& Garassino, 2004}

(Fig. 2C)

STUdied MATERIAL. - 1 specimen from Solnhofen (MNHN.F.A33521).

\section{COMMENTS}

This specimen is the seventh one known as belonging to this species (see Schweigert \& Garassino 2004).
Genus Drobna Münster, 1839

TYPE SPECIES. - Drobna deformis Münster, 1839, by subsequent designation of Glaessner (1929).

Drobna deformis Münster, 1839

(Fig. 2D)

STUDIED MATERIAL. - 1 specimen from Eichstätt (MNHN.F.A33531).

\section{COMMENTS}

The specimen is remarkably long (total length: $14 \mathrm{~cm}$ ) respect to the type specimens housed in the Bayerische Staatssammlung für Paläontologie und Geologie in Munich (total length: between 10.5 and $11.5 \mathrm{~cm}$ ). However, a specimen housed in the same collection has a similar size and comes from the Mörnsheim Formation which overlies the Solnhofen Limestones (Günter Schweigert pers. comm. 2011).

Suborder PLEOCYEMATA Burkenroad, 1963 Infraorder CARIDEA Dana, 1852 Superfamily and Family uncertain

Genus Hefriga Münster, 1839

TyPe sPeCiES. - Hefriga serrata Münster, 1839, by subsequent designation of Glaessner (1929).

Hefriga serrata Münster, 1839

(Fig. 3A)

STUdied MATERIAL. - 1 specimen from Solnhofen (MNHN.GG.2004/8237); 1 specimen from Eichstätt (MNHN.F.B13464). Collections Boué, Manchester Museum.

\section{COMMENTS}

The specimen MNHN.F.B13464 shows very elongate and straight rostrum with only dorsal spines. Therefore, it is different from $H$. rogerfrattigianii Schweigert, 2011, and H. norbertwinkleri Schweigert, 2011, having two and three ventral spines respectively on the rostrum. It is different from $H$. prohoscideawulfi 

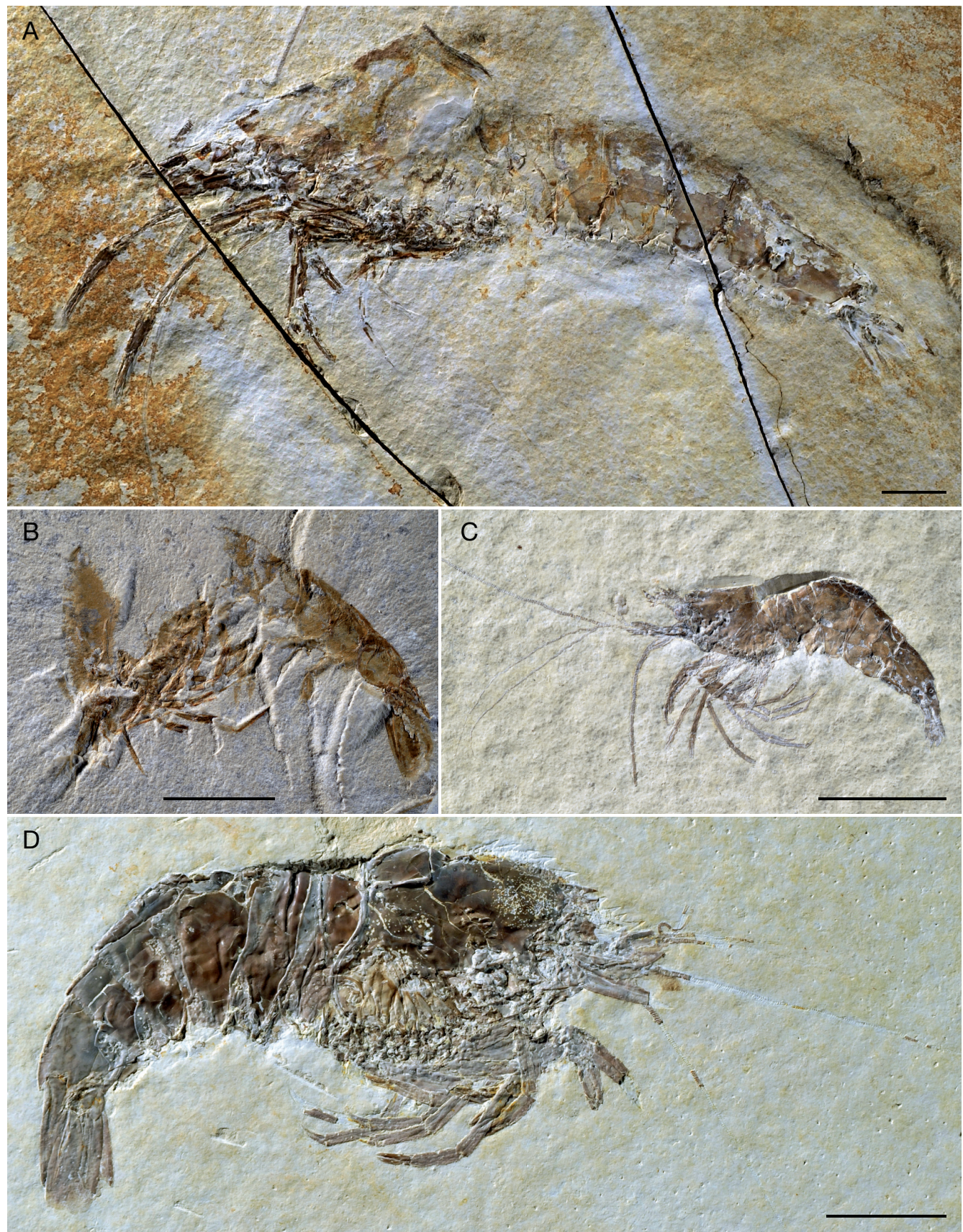

FIG. 2. - Penaeidae from the Late Jurassic Solnhofen Lithographic Limestones (Bavaria, Germany): A, Antrimpos speciosus Münster, 1839, probable exuvia, right lateral view (MNHN.F.R03502, Solnhofen); B, Rauna angusta Münster, 1839, probable exuvia, right lateral view (MNHN.F.A42004, Solnhofen); C, Albertoppelia kuempeli Schweigert \& Garassino, 2004, right lateral view, (MNHN.F.A33521, Solnhofen); D, Drobna deformis Münster, 1839, left lateral view, (MNHN.F.A33531, Eichstätt). Scale bars: $2 \mathrm{~cm}$. Photographs by C. Lemzaouda (MNHN). 
Schweigert \& Garassino, 2004, that has a remarkably long, ventrally curved rostrum. Moreover, the studied specimen shows nine dorsal spines on the rostrum as observed in $H$. frischmanni Oppel, 1862 and $H$. serrata Münster, 1839. As pointed out by Van Straelen (1925: 103), $H$. frischmanni has the same number of rostral spines than $H$. serrata. We here follow the opinion of the first reviewer considering Oppel's species as synonym of the type species and we assign our specimens to $H$. serrata.

Infraorder GLYPHEOIDEA von Zittel, 1885

Superfamily ERYMOIDEA Van Straelen, 1925

Family ERYMIDAE Van Straelen, 1925

Genus Eryma von Meyer, 1840

TYPE SPECIES. - Macrourites modestiformis von Schlotheim, 1822, by subsequent designation of Glaessner (1929).

Eryma modestiforme (von Schlotheim, 1822)

(Fig. 3B, C)

StUdied Material. - 6 specimens from Solnhofen (MNHN.F.A33507, B13448, B13450, B13452, B13463; MNHN.GG.2004/7462); 1 specimen from Eichstätt (MNHN.F.B13446); 1 specimen from unknown locality (MNHN.GG.2004/8078-7471). Collections Boué, Schwarzchild, A. Milne Edwards, Hoffstetter, Manchester Museum.

Comments

Two species of erymids are known from the Solnhofen Lithographic Limestones, Eryma modestiforme and Galicia veltheimii (Münster, 1839). All the studied specimens are ascribed to E. modestiforme for the cephalothoracic groove pattern and also for the short chela strongly tuberculate of pereiopod 1 (elongate and weakly tuberculate in $G$. veltheimii). See Förster (1966) for detailed discussion on the genera of Erymidae.

Genus Palaeastacus Bell, 1850

TYPE SPECIES. - Astacus sussexiensis Mantell, 1833, by subsequent designation of Glaessner (1929).
Palaeastacus fuciformis (von Schlotheim, 1822)

(Fig. 3D)

STUdied MATERial. -2 specimens from Solnhofen (MNHN.F.B13449; MNHN.GG.2004/8245); 1 specimen from unknown locality (MNHN.GG.2004/79988106). Collections Boué, Schwarzchild.

\section{Genus Pustulina Quenstedt, 1857}

TYPE SPECIES. - Pustulina suevica Quenstedt, 1857, by subsequent designation of Glaessner (1929).

Pustulina minuta (von Schlotheim, 1822) (Fig. 3E)

STUDiED MATERIAL. - 2 specimens from Eichstätt (MNHN.F.B13444, B13445); 1 specimen from unknown locality (MNHN.GG.2004/8101). Collections A. Milne Edwards, de Drée.

Family GLYPHEIDAE von Zittel, 1885

Genus Glyphea von Meyer, 1835

TYPE SPECIES. - Palinurus regleyanus Desmarest, 1822, by monotypy.

Glyphea pseudoscyllarus (von Schlotheim, 1822) (Fig. 3F)

STUDiED MATERial. -3 specimens from Solnhofen (MNHN.F.A33506, B13447, B13462); 1 specimen from Eichstätt (MNHN.GG.2004/7463). Collections A. Milne Edwards, du Mouy, Hoffstetter, Manchester Museum.

\section{COMMENTS}

Three species of Glyphea are described at present from the Solnhofen Lithographic Limestones, G. pseudoscyllarus, G. tenuis Oppel, 1860 and G. viohli Polz, 2000. The studied specimens have been ascribed to G. pseudoscyllarus for the chela of pereiopod 1 with longitudinal parallel ridges strongly spinose (chela of pereiopod 1 without ridges and with poorly tuberculate surface both in $G$. tenuis and $G$. viohli). 

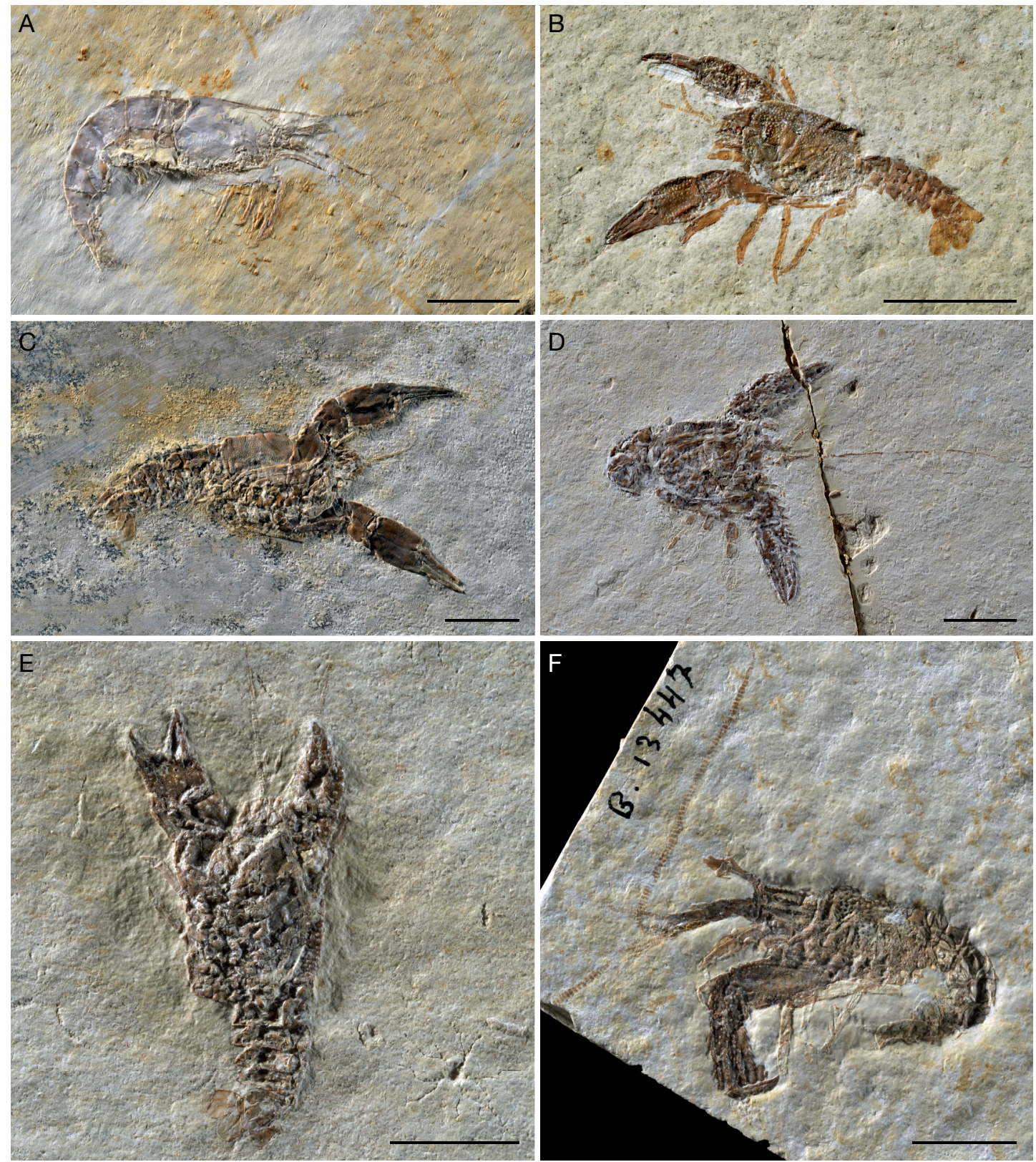

FIG. 3. - Caridea, Erymidae and Glypheidae from the Late Jurassic Solnhofen Lithographic Limestones (Bavaria, Germany): A, Hefriga serrata Münster, 1839, left lateral view (MNHN.F.B13464, Eichstätt); B, Eryma modestiforme (von Schlotheim, 1822), right lateral view (MNHN.F.B13450, Solnhofen); C, E. modestiforme, left lateral view (MNHN.F.B13446, Eichstätt); D, Palaeastacus fuciformis (von Schlotheim, 1822), right lateral view (MNHN.F.B13449, Solnhofen); E, Pustulina minuta (von Schlotheim, 1822), ventral view (MNHN.F.B13444, Eichstätt); F, Glyphea pseudoscyllarus (von Schlotheim, 1822), left lateral view (MNHN.F.B13447, Solnhofen). Scale bars: $1 \mathrm{~cm}$. Photographs by C. Lemzaouda (MNHN). 
Family MeCochiridae Van Straelen, 1925

Genus Mecochirus Germar, 1827

TYPE SPECIES. - Macrourites longimanatus von Schlotheim, 1820, by subsequent designation of Woods (1927).

Mecochirus longimanatus (von Schlotheim, 1820) (Fig. 4A-C)

STUDiED MATERIAL. -20 specimens from Solnhofen (MNHN.F.A33508, A33533, A33534, A33535, A33536, A33537, A33538, A33539, A33540, A33541, A33546, A42007, B13453, B13456, B13457, R03397; MNHN.GG.2004/8073, 2004/8081, 2004/8102, 2004/8232); 2 specimens from Eichstätt (MNHN.F.A33542, B13454); 2 specimens from "Pappenheim" (MNHN.GG.2004/8075, 2004/8231); 3 specimens from unknown locality (MNHN.F.A42005; MNHN.GG.2004/7461, 2004/8080). Collections, Brongniart, Labarre, Boué, A. Milne Edwards, Hoffstetter, Braillon, Rey-Jouvin.

\section{COMMENTS}

Specimens MNHN.F.A42005 (Fig. 4B) and MNHN.F.B13456 (Fig. 4C) show carapaces completely dislocated and disarticulated respect the other parts of the body. They are probably exuviae. For the two specimens labelled as "Pappenheim", see Material and Methods.

Infraorder ACHELATA Scholtz \& Richter, 1995 Family PALINURIDAE Latreille, 1802

Genus Palinurina Münster, 1839

TYPe SPECIES. — Palinurina longipes Münster, 1839, by subsequent designation of Woods (1925).

\section{Palinurina longipes Münster, 1839}

(Fig. 4D)

STUdied MATERial. -5 specimens from Solnhofen (MNHN.F.A30691, A30773, A33510, A33511, A33512); 3 specimens from Eichstätt (MNHN.F.B13455, B13458, B13460). Collections A. Milne Edwards, Hoffstetter.

\section{COMMENTS}

Two species of Palinurina are known at present in the Solnhofen Lithographic Limestones, P. longipes and $P$. tenera Oppel, 1862. The studied specimens have been assigned to the type species for the strongly tuberculate pereiopods and carapace (smooth pereiopods in $P$. tenera in which the carapace is not preserved).

\section{Infraorder POLYCHELIDA \\ Scholtz \& Richter, 1995 \\ Family ERYONIDAE De Haan, 1841 \\ Genus Cycleryon Glaessner, 1965}

TYPE SPECIES. - Macrourites propinquus von Schlotheim, 1822 , by original designation.

Cycleryon propinquus (von Schlotheim, 1822) (Fig. 5A, B)

STUDIED MATERIAL. - 2 specimens from Solnhofen (MNHN.F.B13436; MNHN.F.A42006); 2 specimens from Eichstätt (MNHN.F.A33518, A33543); 1 specimen from an unknown locality (MNHN.GG.2004/8071). Collections A. Milne Edwards, de Drée.

\section{COMMENTS}

Four species of Cycleryon are known at present in the Solnhofen Lithographic Limestones, C. propinquus, C. orbiculatus (Münster, 1839), C. elongatus (Münster, 1839) and C. wulfi Garassino \& Schweigert, 2004. The studied specimens have been assigned to the type species for the spiny lateral margins, the two weak and tuberculate branchial carinae and the strongly tuberculate median postcervical carina. The type species differs from $C$. orbiculatus not having dorsal carinae, from $C$. elongatus having partially spiny lateral margins and from $C$. wulf having unique spiny frontal margin. Moreover, we illustrate the first pereiopod of C. spinimanus (Germar, 1827) considered by Schweigert (2001b) as the female of C. propinquus (MNHN.F.A42006), usually rare in the Solnhofen Lithographic Limestones (Fig. 5B). 

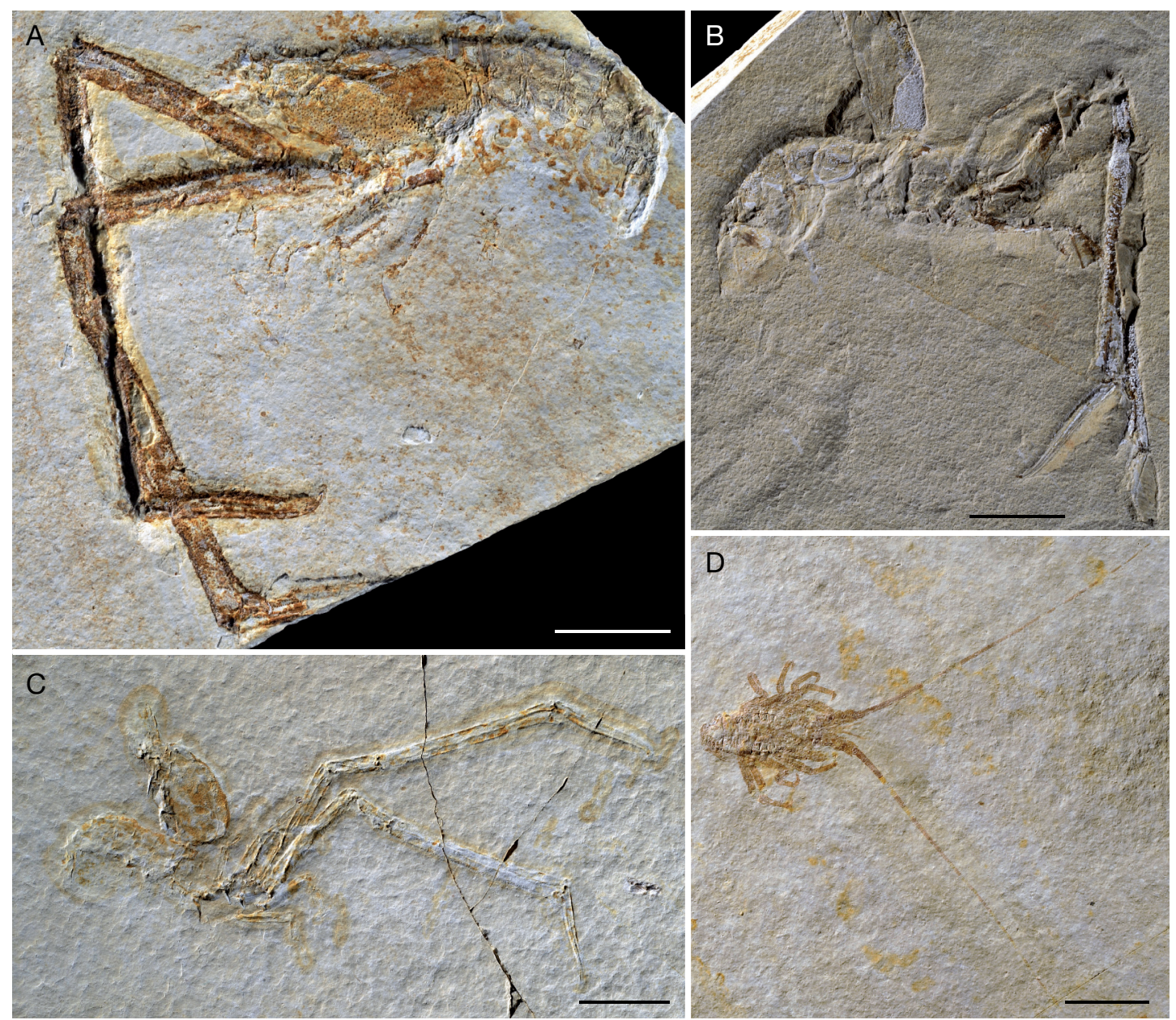

FIG. 4. - Mecochiridae and Palinuridae from the Late Jurassic Solnhofen Lithographic Limestones (Bavaria, Germany): A, Mecochirus longimanatus (von Schlotheim, 1820), left lateral view (MNHN.F.B13454, Eichstätt); B, M. longimanatus, probable exuvia, right lateral view (MNHN.F.A42005, unknown locality); C, M. longimanatus, probable exuvia, right lateral view (MNHN.F.B13456, Solnhofen); D, Palinurina longipes Münster, 1839, ventral view (MNHN.F.B13455, Eichstätt). Scale bars: 2 cm. Photographs by C. Lemzaouda (MNHN).

\section{Cycleryon orbiculatus (Münster, 1839) (Fig. 5C)}

STUdied MATERIAL. - 1 specimen from Solnhofen (MNHN.F.B13434). Collection A. Milne Edwards.

\section{COMMENTS}

The lack of dorsal carinae on the cephalothorax and the smooth frontal margin allows ascribing the specimen to $C$. orbiculatus. This species is relatively rare in the Solnhofen Lithographic Limestones (see Garassino \& Schweigert 2006).

\section{Genus Eryon Desmarest, 1817}

Type SPECIES. - Eryon cuvieri Desmarest, 1817, by monotypy.

\section{Eryon cuvieri Desmarest, 1817 (Fig. 5D)}

TYPE MATERIAL. — Lectotype: MNHN.F.A32407 (coll. Faujas de Saint-Fond) from Solnhofen, designated by Charbonnier et al. (2012); 
Paralectotype: MNHN.F.R65101 (coll. Brongniart, ex. coll. Faujas de Saint-Fond) from Solnhofen.

OTHER MATERIAL. - 9 specimens from Solnhofen (MNHN.F.A33501, A33520, A33544, A33545, B13438, B13451, R03402; MNHN.GG.2004/8220, 2004/8004); 1 specimen from Eichstätt (MNHN.F.B13437); 1 specimen from "Pappenheim" (MNHN.GG.2004/8218); 3 specimens from unknown locality (MNHN.F.B13439; MNHN.GG.2004/7997, 2004/8109). Collections A. Milne Edwards, Schwarzchild, Boué, Hoffstetter, Manchester Museum.

\section{COMMENTS}

Same remark for Pappenheim (see Material and Methods). All the specimens are assigned to $E$. $c u$ vieri, the only species known to date in the Solnhofen Lithographic Limestones (Charbonnier et al. 2012).

\section{Order STOMATOPODA Latreille, 1817 Family SCULDIDAE Dames, 1886}

Genus Sculda Münster, 1840

Type SPeCIES. - Sculda pennata Münster, 1840, by monotypy.

\section{Sculda pennata Münster, 1840}

(Fig. 5E)

STUdied Material. -1 specimen from Solnhofen (MNHN.F.B13466). Collection A. Milne Edwards.

\section{COMMENTS}

Contrary to the Münster's type specimens (1840: pl. 1, figs 7,8$)$, the studied specimen shows wellpreserved telson, uropods, and stalked-eyes.

Superorder PERACARIDA Calman, 1904

Order MYSIDACEA Boas, 1883

Suborder and Family uncertain

Genus Elder Münster, 1839

TYPE SPECIES. - Elder ungulatus Münster, 1839, by subsequent designation of Oppel (1862).

\section{Elder ungulatus Münster, 1839}

STUDIED MATERIAL. - 3 specimens from Solnhofen (MNHN.F.A33549, B13467; MNHN.GG.2004/8217). Collections A. Milne Edwards, Boué.

\section{COMMENTS}

Fossil representatives of Mysidacea are relatively rare and few fossils have been identified to date. Elder ungulatus Münster, 1839, and also Francocaris grimmi Borili, 1917, both from the Jurassic Solnhofen limestones of Bavaria, are generally included among the Mysidacea. However, Schram (1986) and Taylor et al. (2001) did not agree with this attribution. Indeed, they said that these taxa are "too poorly understood to permit an unqualified assignment".

Class MEROSTOMATA Dana, 1852

Order XIPHOSURIDA Latreille, 1802

Family LimULIDAE Riek \& Gill, 1971

Genus Mesolimulus Størmer, 1952

TYPE SPECIES. — Limulus walchii Desmarest, 1817, by monotypy.

\section{Mesolimulus walchii (Desmarest, 1817)} (Fig. 6)

StUdied MATERial. -4 specimens from Solnhofen (MNHN.F.A33516, B13432, B13433; MNHN. GG.2004/7473). Collections A. Milne Edwards, Stuer.

\section{Comments}

Desmarest (1817) described Limulus walchii, a new limulid from the Jurassic of Solnhofen (Bavaria, Germany). In his famous monograph with A. Brongniart, Desmarest (1822) made the same description. Then numerous authors, ignoring the first Desmarest's work, used this taxon with the date of 1822 . The correct combination is thus Mesolimulus walchii (Desmarest, 1817).

\section{Acknowledgements}

We thank Günter Schweigert (Staatliches Museum für Naturkunde, Stuttgart, Germany) for his 

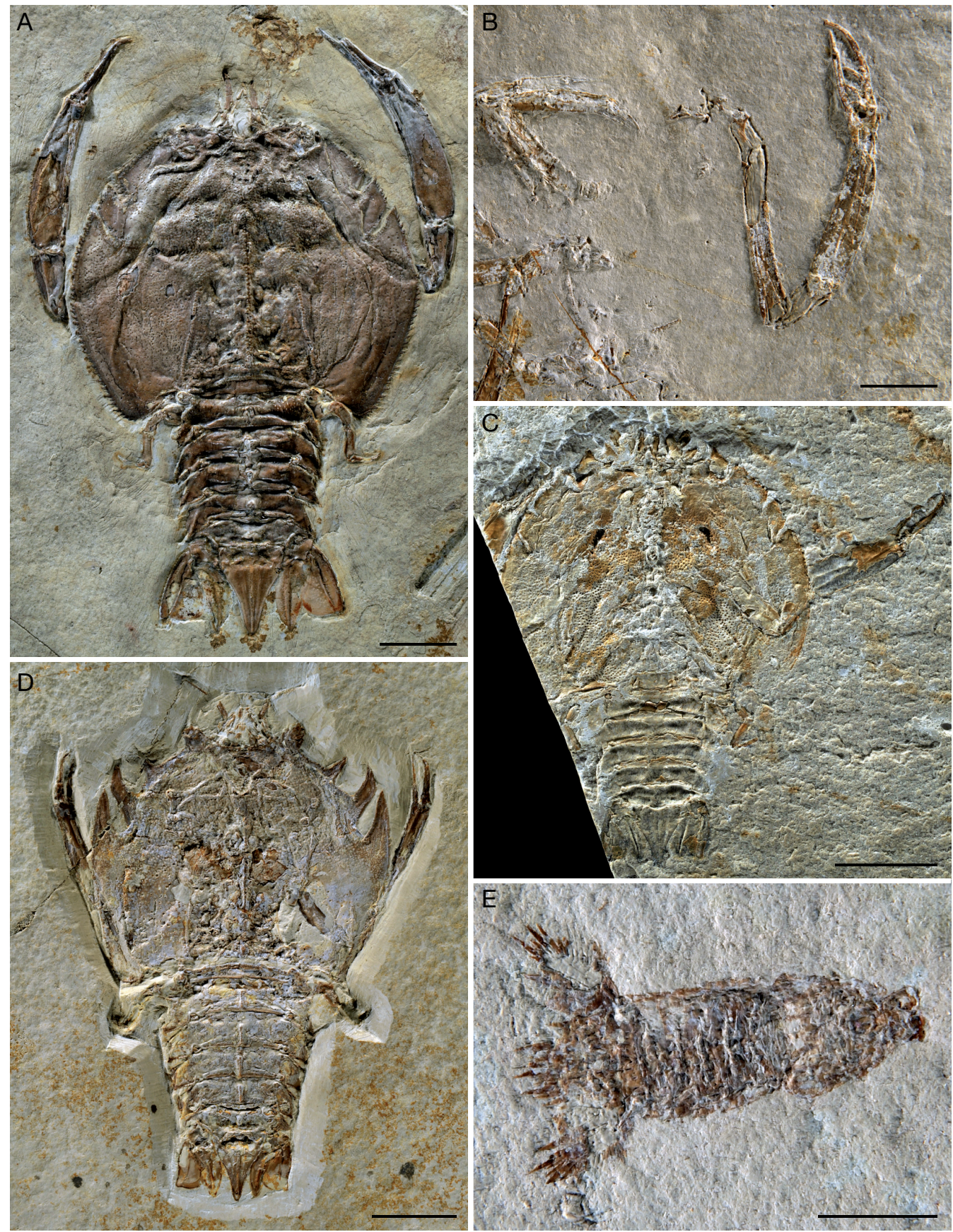

FIG. 5. - Eryonidae and Sculdidae from the Late Jurassic Solnhofen Lithographic Limestones (Bavaria, Germany): A, Cycleryon propinquus (von Schlotheim, 1822), dorsal view (MNHN.F.A33518, Eichstätt); B, first pereiopod of C. spinimanus (Germar, 1827) considered as the female of C. propinquus, probable exuvia (MNHN.F.A42006, Solnhofen); C, C. orbiculatus (Münster, 1839), dorsal view (MNHN.F.B13434, Solnhofen); D, Eryon cuvieri Desmarest, 1817, dorsal view (MNHN.F.R03402, Solnhofen); E, Sculda pennata Münster, 1840, dorsal view (MNHN.F.B13466, Solnhofen). Scale bars: A-D, H, 2 cm; E, 1 cm. Photographs by C. Lemzaouda (MNHN). 


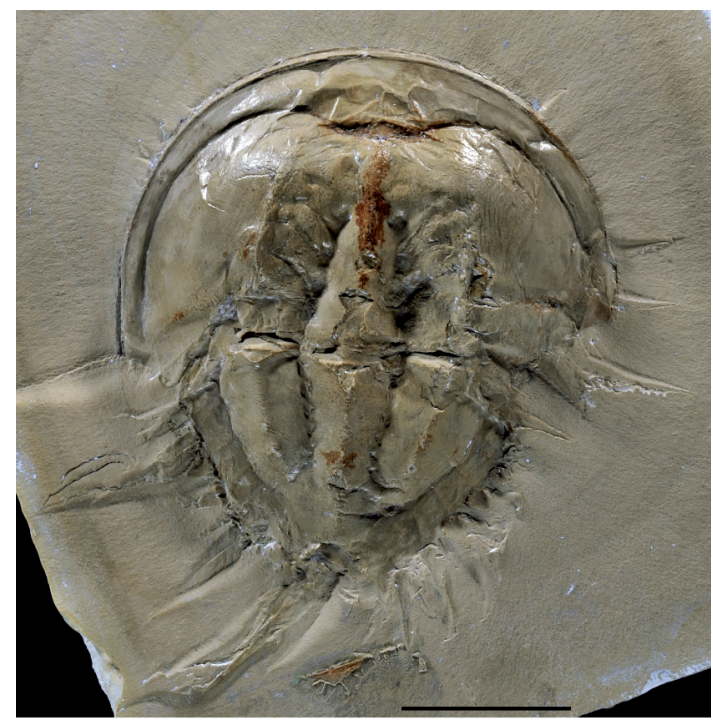

FIG. 6. - Mesolimulus walchii (Desmarest, 1817) (Xiphosurida, Limulidae) from the Late Jurassic Solnhofen Lithographic Limestones (Bavaria, Germany), dorsal view (MNHN.F.A33516, Solnhofen). Scale bar: $4 \mathrm{~cm}$. Photograph by $\mathrm{C}$. Lemzaouda (MNHN).

useful information about the Solnhofen Lithographic Limestones. We really thank Marie-Astrid Angel (Bibliothèque de Paléontologie, MNHN) and Sophie Guillon (Bibliothèque de Géologie, MNHN) for their useful historical researches and also Christian Lemzaouda (Département Histoire de la Terre, MNHN) for assistance in photographic work. We also thank Jean-Claude Gall and Annemarie Ohler for their reviews. This paper is a contribution from the Museo di Storia Naturale di Milano (Paleontology Department), and the UMR CNRS 7207 Centre de Recherche sur la Paléobiodiversité et les Paléoenvironnements as well as the Département Histoire de la Terre (MNHN, Paris).

\section{REFERENCES}

BRYGOO E. R. 2002. - Alcide d'Orbigny et l'ingratitude de ses pairs, in TAQUeT P. (ed.), Alcide d'Orbigny, du Nouveau Monde au passé du monde. Nathan \& Muséum national d'Histoire naturelle, Paris: 119-120.

Charbonnier S., Garassino A., Pacaud J.-M. \& SChweIgert G. 2012. - Rediscovery of the type material of Eryon cuvieri Desmarest, 1817 (Crustacea, Decapoda, Eryonidae) and nomenclatural consequences. Geodiversitas 34 (4): 849-855. http:// dx.doi.org/10.5252/g2012n4a7

De Grave S., Pontcheff N. D., Ahyong S. T., Chan T.-Y., Crandall K. A., DworschaK P. C., Felder D. L., Feldmann R. M., Fransen C. H. M., Goulding L. Y. D., Lemaitre R., Low M. E. Y., MarTin J. W., NG P. K. L., SChWeITZER C. E., TAN S. H., Tshudy D. \& WeTZER R. 2009. - A classification of living and fossil genera of decapod crustaceans. The Raffles Bulletin of Zoology, Supplement 21: 1-109.

Desmarest A.-G. 1817. - Crustacés fossiles, in Société de Naturalistes et d'Agriculteurs (eds), Nouveau Dictionnaire d'Histoire naturelle, appliquée aux Arts, à l'Agriculture, à l'Économie rurale et domestique, à la Médecine, etc. Tome 7 [COR-CUN]. Deterville, Paris: 495-519.

DESMAREST A.-G. 1822. — Les crustacés proprement dits, in Brongniart A. \& Desmarest A.-G. (eds), Histoire naturelle des crustacés fossiles sous les rapports zoologiques et géologiques. F.-G. Levrault, Libraire, Paris: 67-142.

FÖRSTER R. 1966. - Über die Erymiden, eine alte konservative Familie der mesozoischen Dekapoden. Palaeontographica 125 (4-6): 61-175.

Garassino A. \& SCHWEIGERT G. 2006. - The Upper Jurassic Solnhofen decapod crustacean fauna: review of the types from old descriptions. Part I. Infraorders Astacidea, Thalassinidea, and Palinura. Memorie della Società italiana di Scienze naturali e del Museo civico di Storia naturale di Milano 34 (1): 1-64.

Glaessner M. F. 1929. - Crustacea Decapoda, in POMPECKJ J. F. (ed.), Fossilium Catalogus, I: Animalia, Pars 41: 1-464.

OpPel A. 1862. - Über jurassische Crustaceen (Decapoda macrura). Palaeontologische Mittheilungen aus dem Museum des koeniglich Bayerischen Staates 1: 1-120.

Polz H. 1970. — Zur Unterscheidung von Phalangites priscus Münster und Palpipes cursor Roth (Arthropoda) aus den Solnhofener Plattenkalken. Neues Jahrbuch für Geologie und Paläontologie, Monatshefte 1970 (12): 705-22.

Polz H. 1972. - Entwicklungsstadien bei fossilen Phyllosomen (Form A) aus den Solnhofener Plattenkalken. Neues Jahrbuch für Geologie und Paläontologie, Monatshefte 1972 (11): 678-689.

Polz H. 1973. - Entwicklungsstadien bei fossilen Phyllosomen (Form B) aus den Solnhofener Plattenkalken. Neues Jahrbuch für Geologie und Paläontologie,Monatshefte 1973 (5): 284-296.

SCHRAM F. R. 1986. - Crustacea. Oxford University Press, Oxford, $606 \mathrm{p}$.

SCHWeigerT G. 2001a. - The late Jurassic decapod species Aeger tipularius (Schlotheim, 1822) (Crustacea: Decapoda: Aegeridae). Stuttgarter Beiträge zur 
Naturkunde, Serie B 309: 1-10.

SCHWEIGERT G. 2001b. - Dimorphismus bei Krebsen der Gattung Cycleryon (Decapoda, Eryonidae) aus dem Oberjura Süddeutschlands. Stuttgarter Beiträge zur Naturkunde, Serie B 305: 1-21.

SCHWEIGERT G. 2007. — Ammonite biostratigraphy as a tool for dating Upper Jurassic lithographic limestones from South Germany - first results and open questions. Neues Jahrbuch für Geologie und Paläontologie, Abhandlungen 245: 117-125.

Schweigert G. \& GARASSino A. 2004. - New genera and species of shrimps (Crustacea: Decapoda: Dendrobranchiata, Caridea) from the Upper Jurassic lithographic limestones of S Germany. Stuttgarter Beiträge zur Naturkunde B 350: 1-33.
TAYlOR R. S., SCHRAM F. R. \& YAN-BIN S. 2001. A new Upper Middle Triassic shrimp (Crustacea: Lophogastrida) from Guizhou, China, with discussion regarding other fossil "Mysidaceans". Journal of Paleontology 75 (2): 310-318.

Van Straelen V. 1925. - Contribution à l'étude des crustacés décapodes de la période jurassique. $M e ́-$ moires de la Classe des Sciences de l'Académie royale de Belgique 7: 1-462.

VéneC-Peyré M.-T. 2002. — Alcide d'Orbigny (18021857) : sa vie et son œuvre. Comptes Rendus Palevol 1 (6): 313-323.

Woods H. 1925-1931. - A monograph of the fossil macrurous Crustacea of England. Palaeontographical Society of London, London, $122 \mathrm{p}$.

Submitted on 16 May 2011; accepted on 28 September 2011. 